\title{
PENGARUH RETURN ON ASSETS, CORPORATE GOVERNANCE DAN KARAKTER EKSEKUTIF TERHADAP TAX AVOIDANCE \\ (Pada Sektor Pertambangan yang terdaftar di Bursa Efek Indonesia Tahun 2013-2017)
}

\section{Perpajakan}

\author{
Himatul Aulia ${ }^{1)}$, Sumarno ${ }^{2)}$, Dewi Indriasih ${ }^{3)}$ \\ hima.aulia@yahoo.co.id \\ Fakultas Ekonomi dan Bisnis \\ Universiitas Pancasakti Tegal
}

\begin{abstract}
This study aims to examine the effect of return on assets, corporate governance and characteristic of executive the extent of tax avoidance to mining companies which is listed on the Indonesia stock exchange. Elements of return on assets, corporate governance that is used is the ownership of institutional, independent commissioner, audit committee and characteristic of executive (company risk). The population in this study was all mining companies which is listed on the Indonesia stock exchange 2013 until 2017. The study sample was determined by the purposive sampling method and obtain 35 companies. Type of data used was secondary data obtained from the www.idx.co.id and corporate websites. The method of analysis that used is regression analysis multiple. Based on the result of multiple regression analysis of this study concluded that: (1) return on assets has effect the tax avoidance with a significance value 0,015 $<0,05$ (2) ownership institutional has effect the tax avoidance with a significance value 0,000 < 0,05 (3) independent commissioner has effect the tax avoidance with a significance value 0,032 $<0,05$ (4) audit committee has not effect the tax avoidance with a significance value 0,184 > 0,05 (5) risk company has not effect the tax avoidance with a significance value 0,077 > 0,05.
\end{abstract}

Keywords: Return on Assets, Corporate Governance, Ownership Institutional, Independent Commissioner, audit committee, Company Risk, Tax Avoidance.

\begin{abstract}
ABSTRAK
Penelitian ini bertujuan untuk menguji pengaruh return on assets, corporate governance dan karakter eksekutif terhadap tax avoidance pada Perusahaan Pertambangan yang Terdaftar di Bursa Efek Indonesia. Mekanisme return on assets, corporate governance (kepemilikan institusional, komisaris independen, komite audit) dan karakter eksekutif (risiko perusahaan). Populasi dalam penelitian ini adalah seluruh Perusahaan Pertambangan yang Terdaftar di Bursa Efek Indonesia tahun 2013 sampai 2017. Sedangkan sampel penelitian ini ditentukan dengan metode purposive sampling sehingga diperoleh 35 data perusahaan sampel. Jenis data yang digunakan adalah data sekunder yang diperoleh dari www.idx.co.id dan website perusahaan. Metode analisis yang digunakan adalah analisis regresi linear berganda. Berdasarkan hasil analisis regresi linear berganda hasil penelitian ini menyimpulkan: (1) Return on Assets berpengaruh signifikan terhadap tax avoidance dengan nilai signifikansi 0,015 < 0,05 (2) Kepemilikan Institusional berpengaruh signifikan terhadap tax avoidance dengan nilai signifikansi 0,000 <0,05 (3) Komisaris Independen berpengaruh signifikan terhadap tax avoidance dengan nilai signifikansi 0,032 <0,05 (4) Komite Audit tidak berpengaruh signifikan terhadap tax avoidance dengan nilai signifikansi 0,185 >0,05
\end{abstract}


(5) Risiko Perusahaan tidak berpengaruh signifikan terhadap tax avoidance dengan nilai signifikansi 0,77 >0,05.

\section{Kata Kunci: Return on Assets, Corporate Governance, Kepemilikan Institusional, Komisaris Independen, Komite Audit dan Risiko Perusahaan, Tax Avoidance.}

\section{PENDAHULUAN}

Sejak zaman Sebelum Masehi pajak telah dipungut oleh penguasa suatu daerah, untuk kepentingan penguasa itu sendiri, tanpa memperhatikan kesejahteraan rakyatnya. Setiap negara atau daerah telah mengakui betapa pentingnya penghimpunan dana dari rakyat baik itu untuk penguasa dengan tidak memperhatikan rakyat atau juga digunakan untuk kesejahteraan rakyatnya (Rahayu, 2010:8). Peran pajak yang dominan untuk menopang penerimaan suatu negara telah membuatnya menjadi primadona sumber penggalangan dana (Purwono, 2010:12). Indonesia termasuk negara yang masih mengandalkan penerimaan utamanya dari sektor pajak yang ditarik dari masyarakat (Siregar, 2012 dalam Amri, 2017).

Salah satu pengelolaan beban pajak yang dapat diterapkan tanpa melanggar peraturan perpajakan yang ada adalah dengan melakukan penghindaran pajak yang dapat diterima fiskus (Hardianti, 2014 dalam Lestari dan Putri, 2017). Penghindaran pajak (tax avoidance) merupakan contoh strategi yang dapat digunakan oleh manajemen perusahaan untuk melakukan penghematan atas beban perusahaan yang pada akhirnya dapat meningkatkan laba bersih perusahaan. Para ahli dan akademisi masih berbeda dalam menggunakan istilah, secara umum pengertian dari penghindaran pajak dapat didefinisikan sebagai segala upaya yang dilakukan perusahaan untuk meminimumkan jumlah pajak yang harus dibayarkan kepada negara (Amri, 2017). Sifat tax avoidance yang sah menurut hukum membuat pemerintah tidak dapat menjatuhkan sanksi bahkan ketika ada indikasi skema tax avoidance akan dilakukan oleh perusahaan (Butje dan Tjondro, 2014).

Berita mengenai penghindaran pajak berdasarkan laporan yang dibuat bersama antara Ernesto Crivelly, penyidik dari IMF tahun 2016, berdasarkan survei, lalu di analisa kembali oleh Universitas PBB menggunakan database
International Center for Policy and Research (ICPR), dan International Center for Taxation and Development (ICTD) muncullah data penghindaran pajak perusahaan 30 negara. Indonesia masuk ke peringkat 11 terbesar dengan nilai diperkirakan 6,48 miliar dolar AS, pajak perusahaan tidak dibayarkan perusahaan yang ada di Indonesia ke Dinas Pajak Indonesia (Susilo, R. (2017). Indonesia Masuk Peringkat ke-11 Penghindaran Pajak Perusahaan, Jepang No.3.Online.http://www.tribunnews.com/ internasional/2017/11/20/indonesia-masukperingkat-ke-11-penghindaran-pajakperusahaan-jepang-no3.(16 Februari 2018).

\section{Kerangka Pemikiran dan Hipotesis \\ 1. Pengaruh return on assets terhadap tax avoidance. \\ Return on asset (ROA) merupakan} satu indikator yang mencerminkan kinerja operasional perusahaan dan ROA dapat dijadikan sebagai pengukur keuntungan bersih yang diperoleh dari penggunaan asset (Handayani, Aris dan Mujiyati 2015). Semakin tinggi nilai ROA berarti semakin baik kinerja perusahaan dengan menggunakan aset sehingga diperolehnya laba yang besar. Laba yang meningkat berakibat pada ROA yang juga meningkat. Meningkatnya laba berdampak pada pajak terutang yang semakin besar. Perusahaan akan berupaya untuk mengecilkan atau meminimalkan pajak yang terutang. Dengan demikian ada kemungkinan bagi perusahaan untuk melakukan penghindaran pajak (Annisa, Taufik dan Hanif, 2017).

\section{Pengaruh kepemilikan institusional terhadap tax avoidance.}

Kepemilikan institusional merupakan kepemilikan saham yang dimiliki oleh institusi seperti pemerintah, perusahaan asuransi, investor luar negeri, atau bank 
kecuali kepemilikan individual (Damayanti dan Susanto, 2015). Kepemilikan institusional sebagai pengawas yang berasal dari luar perusahaan memegang peranan penting dalam memonitoring manajemen (Maharani dan Suardana 2014). Perusahaan yang memiliki kepemilikan institusional yang tinggi akan semakin agresif dalam meminimalisir pelaporan perpajakannya (Nurindah, 2013 dalam Diantari dan Ulupui, 2016). Semakin besar kepemilikan institusional maka semakin kuat kendali pihak eksternal terhadap perusahaan, sehingga memungkinkan terjadinya praktik penghindaran pajak (tax avoidance) (Nursari, Diamonalisa dan Sukarmanto, 2017).

\section{Pengaruh komisaris independen terhadap tax avoidance.}

Komisaris independen didefinisikan sebagai seorang yang tidak terafiliasi dalam segala hal dalam pemegang saham pengendali. Tidak memiliki hubungan afiliasi dengan direksi atau dewan komisaris, serta tidak menjabat sebagai direktur pada suatu perusahaan yang terkait (Winata, 2014). Komisaris independen harus menjamin agar mekanisme pengawasan berjalan secara efektif dan juga sesuai dengan undangundang yang telah ditentukan (Okrayanti, Utomo dan Nuraina, 2017). Semakin besarnya persentase dewan komisaris independen dalam struktur dewan komisaris maka semakin tinggi penghindaran pajak yang ditimbulkan (Wibawa, Wilopo dan Abdillah, 2016).

\section{Pengaruh komite audit terhadap tax avoidance.}

Komite audit telah menjadi komponen umum dalam struktur corporate governance perusahaan publik (Cahyono, Andini dan Raharjo, 2016). Berjalannya komite audit dalam suatu perusahaan dapat meminimalkan kecurangan dalam laporan keuangan yang dilakukan oleh pihak manajemen (Syaputra dan Asyik, 2017). Sementara BEI mensyaratkan paling sedikit H5 : Diduga komite audit berpengaruh signifikan terhadap tax avoidance. komite audit harus tiga orang. Jadi jika kurang dari tiga orang maka tidak sesuai dengan peraturan BEI. Dengan demikian, apabila jumlah komite audit dalam suatu perusahaan tidak sesuai dengan peraturan BEI maka akan meningkatkan tindakan manajemen dalam melakukan minimalisasi laba untuk kepentingan penghindaran pajak (taxavoidance) (Sandy dan Lukviarman, 2015).

\section{Pengaruh risiko perusahaan terhadap tax avoidance.}

Risiko perusahaan adalah risiko yang terjadi pada perusahaan dan akan berdampak pada kelangsungan hidup usaha tersebut (Dewi dan Jati, 2014). Besar kecilnya risiko perusahaan mencerminkan apakah eksekutif perusahaan termasuk dalam kategori risk taking atau risk averse, semakin besar risiko perusahaan menunjukan eksekutif perusahaan tersebut adalah risk taking, sebaliknya semakin kecil risiko perusahaan menunjukan eksekutif perusahaan tersebut adalah risk averse (Damayanti dan Susanto, 2015). Eksekutif yang semakin bersifat risk taker kemungkinan akan lebih besar melakukan tindakan tax avoidance. Tingkat risiko perusahaan yang besar mengindikasikan bahwa pimpinan perusahaan lebih bersifat risk taker yang lebih berani mengambil risiko (Maharani dan Suardana 2014).

Berdasarkan rumusan masalah dan kerangka pemikiran yang telah dijelaskan diatas, maka hipotesis penelitian dapat dijelaskan sebagai berikut:

H1 : Diduga return on assets, kepemilikan institusional, komisaris independen, komite audit dan risiko perusahaan secara simultan berpengaruh signifikan terhadap tax avoidance. $\mathrm{H} 2$ : Diduga return on assets berpengaruh signifikan terhadap tax avoidance.

H3 : Diduga kepemilikan institusional berpengaruh siginfikan terhadap tax avoidance.

H4 : Diduga komisaris independen berpengaruh signifikan terhadap tax avoidance. H6 : Diduga risiko perusahaan berpengaruh signifikan terhadap tax avoidance. 


\section{Metode Penelitian}

\section{A. Pemilihan Metode}

Pemilihan metode dalam penelitian ini berbentuk penelitian kuantitatif karena data penelitian berupa angka dan analisis menggunakan statistik. Menurut Ghozali (2013:19) memberikan gambaran atau deskripsi suatu data yang dilihat dari nilai rata-rata (mean), standar deviasi, varian, maksimum, minimum, sum, range, kurtosis dan skewness (kemencengan distribusi). Sumber data yang digunakan dalam penelitian ini adalah data sekunder.

\section{B. Teknik Pengambilan Sampel}

\section{Populasi}

Populasi (population) mengacu pada keseluruhan kelompok orang, kejadian atau hal minat yang ingin peneliti investigasi (Sekaran, 2006:121). Populasi dalam penelitian ini adalah perusahaan pertambangan yang terdaftar di BEI periode 2013-2017. Saat ini terdapat 41 perusahaan pertambangan

\section{HASIL DAN PEMBAHASAN}

1. Hasil Uji Statistik Deskriptif

Berdasarkan hasil pengolahan data dengan bantuan SPSS (Statistical Product and Service Solution) versi 22 diperoleh tabel hasil perhitungan statistik deskriptif sebagai berikut:

\section{Tabel 4.4}

Hasil Statistik Deskriptif

Descriptive Statistics

\begin{tabular}{|l|r|r|r|r|r|}
\hline & \multicolumn{1}{|c|}{ N } & Minimum & Maximum & \multicolumn{1}{l|}{ Mean } & Std. Deviation \\
\hline Return on Assets & 35 & .0218 & .2068 & .094694 & .0556940 \\
Kepemilikan Institusional & 35 & .2797 & .9700 & .638366 & .1802312 \\
Komisaris Independen & 35 & .0000 & .5000 & .353154 & .1019738 \\
Komite Audit & 35 & 3.0000 & 4.0000 & 3.142857 & .3550358 \\
Risiko Perusahaan & 35 & .0000 & .0120 & .001586 & .0035632 \\
Tax Avoidance & 35 & .2353 & .5247 & .326417 & .0814970 \\
Valid N (listwise) & 35 & & & & \\
\hline
\end{tabular}

Sumber: Data diolah (Output SPSS 22), 2018

\section{Hasil Uji Asumsi Klasik}

2. Dalam penelitian ini, metode pengambilan sampel yang digunakan adalah purposive sampling (pengambilan sampel disengaja).Adapun kriteria sampel dalam memilih dan menetukan kriteria sampel, yaitu:

a. Perusahaan pertambangan.

b. Memiliki laporan keuangan selama 5 tahun berturut-turut (tahun 2013-2017).

c. Perusahaan yang tidak mengalami kerugian selama 5 tahun berturut-turut yaitu periode 2013-2017.

Perusahaan memiliki semua data yang diperlukan untuk variabel-variabel yang telah ditentukan sebelumnya.

\section{Teknik Pengumpulan Data}

Teknik pengumpulan data yang digunakan dalam penelitian ini yaitu teknik dokumentasi. www.idx.co.id data-data tersebut berupa laporan keuangan tahunan dari perusahaan pertambangan periode 2013-2017 yang adalah pengumpulan data dengan melihat, menggunakan dan mempelajari data-data yang diperoleh dari website BEI. dijadikan sampel penelitian.Teknik dokumentasi 
Hasil dari uji asumsi klasik yang digunakan adalah sebagai berikut:

a. Uji Multikolonieritas

Berdasarkan hasil uji multikolonieritas menunjukkan bahwa masing-masing variabel yakni Return on Assets memiliki Tolerance sebesar 0,632 dan Variance Inflation Factor (VIF) sebesar 1,582, Kepemilikan Institusional memiliki Tolerance sebesar 0,686 dan Variance Inflation Factor (VIF) sebesar 1,457, Komisaris Independen memiliki Tolerance sebesar 0,828 dan Variance Inflation Factor (VIF) sebesar 1,207, Komite Audit memiliki Tolerance sebesar 0,788 dan Variance Inflation Factor (VIF) sebesar 1,270, Risiko Perusahaan memiliki Tolerance sebesar 0,760 dan Variance Inflation Factor (VIF) sebesar 1,315. Dapat disimpulkan bahwa semua variabel memiliki nilai Tolerance lebih dari 0,10 dan VIF kurang dari 10 yang berarti bahwa kelima variabel independent dalam penelitian ini tidak terjadi multikolonieritas.

b. Uji Autokorelasi

Berdasarkan hasil ujii autokorelasi menunjukkan bahwa nilai Durbin-Waston (DW) untuk tax avoidance adalah 2,148, maka dapat diketahui nilai dari tabel Durbin-Waston (DW) nilai dl sebesar 1,1601 dan sebesar nilai du 1,8029. Kriteria yang digunakan adalah apabila nilai du < DW < 4 - du maka tidak terjadi autokorelasi. Nilai 4 - du adalah 2,1971 (4 - 1,8029) maka diperoleh hasil 1,8029 < $2,1480<2,1971$. Artinya adalah tidak terjadi autokorelasi.

c. Uji Heteroskedastisitas
Berdasarkan hasil uji heteroskedastisitas menunjukkan bahwa titik-titik tidak membentuk pola yang jelas, serta titik-titik juga menyebar di atas dan di bawah angka 0 pada sumbu Y. Hal ini dapat disimpulkan bahwa tidak terjadi heteroskedastisitas pada model regresi, sehingga model regresi layak dipakai untuk memprediksi tax avoidance berdasarkan masukan variabel independen return on asset, corporate governance dan karakter eksekutif.

\section{d. Uji Normalitas}

Adapun hasil uji normalitas dengan menggunakan grafik normal plot dalam penelitian ini adalah sebagai berikut:

Berdasarkan hasil dari uji grafik normal plot menunjukkan bahwa data menyebar disekitar garis diagonal dan mengikuti arah garis diagonal, maka model regresi dapat memenuhi asumsi normalitas. Adapun hasil uji normalitas penelitian ini dengan menggunakan tabel Kolmogorov-smirnov sebagai berikut:

Berdasarkan hasil output pengolahan data uji normalitas dengan menggunakan rumus Kolmogrov-Smirnov Test sebagaimana terterapada tablel 4.6, maka diperoleh nilai Asymp. Sig. (2-tailed) sebesar 0,086 atau lebih besar dari 0,05 . Sehingga dapat disimpulkan bahwa data yang diuji berdistribusi normal.

\section{Analisis Regresi Linear Berganda}

Model regresi berganda dalam penelitian inidigunakan untuk menyatakan hubungan fungsional antara variabel bebas dan variabel terikat. Berikut merupakan hasil analisis regresi linear berganda:

\section{Tabel 4.8}

\section{Hasil Analisis Regresi Linear Berganda}

\section{Coefficients $^{\mathrm{a}}$}

\begin{tabular}{|c|c|c|c|c|c|}
\hline \multirow[b]{2}{*}{ Model } & \multicolumn{2}{|c|}{$\begin{array}{c}\text { Unstandardized } \\
\text { Coefficients }\end{array}$} & \multirow{2}{*}{$\begin{array}{c}\begin{array}{c}\text { Standardized } \\
\text { Coefficients }\end{array} \\
\text { Beta }\end{array}$} & \multirow[b]{2}{*}{$\mathrm{t}$} & \multirow[b]{2}{*}{ Sig. } \\
\hline & B & Std. Error & & & \\
\hline 1 (Constant) & .594 & .078 & & 7.652 & .000 \\
\hline Return on Assets & -.450 & 173 & -.308 & -2.600 & .015 \\
\hline Kepemilikan Institusional & -.281 & .051 & -.622 & -5.475 & .000 \\
\hline Komisaris Independen & .187 & .083 & .233 & 2.257 & .032 \\
\hline Komite Audit & -.033 & .024 & -.144 & -1.359 & .185 \\
\hline Risiko Perusahaan & -4.531 & 2.469 & -.198 & -1.835 & .077 \\
\hline
\end{tabular}

a. Dependent Variable: Tax Avoidance

Sumber: Data Diolah (Output SPSS 22), 2018 
Hasil uji analisis regresi linear berganda yang terlihat pada tabel 4.6, maka dapat dirumuskan persamaan regresi linear berganda sebagai berikut:

$$
Y=0,594-0,450 \times 1-0,281 \times 2+0,187 \times 3-0,033 \times 4-4,531 \times 5+e
$$

Pengujian terhadap hipotesis yang digunakan dalam penelitian ini dilakukan dengan cara sebagai berikut:

\section{a. Pengujian Secara Simultan (Uji F)}

Tabel 4.9

Hasil Uji Hipotesis F ANOVAa

\begin{tabular}{|l|r|r|r|r|r|}
\hline & \multicolumn{1}{|c|}{$\begin{array}{c}\text { Sum of } \\
\text { Squares }\end{array}$} & $\mathrm{df}$ & $\begin{array}{c}\text { Mean } \\
\text { Square }\end{array}$ & $\mathrm{F}$ & Sig. \\
\hline 1 Regression & .168 & 5 & .034 & 16.768 & $.000 \mathrm{~b}$ \\
Residual & .058 & 29 & .002 & & \\
Total & .226 & 34 & & & \\
\hline
\end{tabular}

a. Dependent Variable: Tax Avoidance

b. Predictors: (Constant), Risiko Perusahaan, Kepemilikan Institusional, Komisaris Independen, Komite Audit, Return on Assets

Sumber: Data Diolah (Output SPSS 22), 2018

Berdasarkan hasil uji hipotesis $\mathrm{F}$ atau ANOVA yang ditunjukkan pada tabel 4.8, terdapat nilai hitung $\mathrm{F}$ adalah sebesar 16,768 dengan tingkat signifikan 0,000 yang jauh lebih kecil dibandingkan 0,05. Maka dari model regresi ini dapat disimpulkan bahwa return on assets, corporate governance (kepemilikan institusional, komisaris independent, komite audit) dan karakter eksekutif (risiko perusahaan) berpengaruh signifikan terhadap tax avoidance.

\section{b. Pengujian Secara Parsial (Uji Statistik t)}

Dari hasil uji t yang dilihat di tabel 4.10 dapat disimpulkan hasil sebagai berikut:

a. Hipotesis yang menyatakan bahwa diduga return on asset berpengaruh signifikan terhadap tax avoidance terbukti, dengan nilai signifikan 0,015 < 0,05 maka hipotesis diterima.

b. Hipotesis yang menyatakan bahwa diduga kepemilikan institusional c. Koefisien Determinasi (Adjusted $\mathbf{R}^{\mathbf{2}}$ ) berpengaruh signifikan terhadap tax avoidance terbukti, dengan nilai signifikan $0,000<0,05$ maka hipotesis diterima.

c. Hipotesis yang menyatakan bahwa diduga komisaris independen berpengaruh signifikan terhadap tax avoidance terbukti, dengan nilai signifikan $0,032<0,05$ maka hipotesis diterima.

d. Hipotesis yang menyatakan bahwa diduga komite audit berpengaruh signifikan terhadap tax avoidance tidak terbukti, dengan nilai signifikan 0,185 > 0,05 maka hipotesis ditolak.

Hipotesis yang menyatakan bahwa diduga risiko perusahaan berpengaruh signifikan terhadap tax avoidance tidak terbukti, dengan nilai signifikan 0,077>0,05 maka hipotesis ditolak. 
Tabel 4.11

Uji Koefisien Determinasi

\begin{tabular}{|l|l|r|r|c|}
\multicolumn{7}{c|}{ Model Summary } \\
\hline Model & R & R Square & Adjusted R Square & $\begin{array}{c}\text { Std. Error of the } \\
\text { Estimate }\end{array}$ \\
\hline 1 & $.862^{\mathrm{a}}$ & .743 & .699 & .0447353 \\
\hline
\end{tabular}

a. Predictors: (Constant), Risiko Perusahaan, Kepemilikan Institusional, Komisaris Independen, Komite Audit, Return on Assets

b. Dependent Variable: Tax Avoidance

Sumber: Data Diolah (Output SPSS 22), 2018

Dari hasil uji koefisien determinasi yang dijelaskan pada tabel 4.11 dapat diketahui bahwa nilai koefisien determinasi $\left(\mathrm{R}_{2}\right)$ sebesar 0,699 atau sebesar $69,9 \%$. Hal ini menunjukkan bahwa 69,9\% dari variabel dependen tax avoidance dapat dijelaskan atau dipengaruhi oleh variabel independent yaitu return on assets, kepemilikan institusional, komisaris independent, komite audit dan risiko perusahaan. Sedangkan sisanya yaitu 0,301 atau sebesar $30,1 \%$ dijelaskan atau dipengaruhi oleh variabel-variabel lainnya.

\section{KESIMPULAN DAN SARAN}

A. Kesimpulan

Berdasarkan hasil dari pengolahan, pengujian dan analisis data yang dilakukan penulis maka dapat disimpulkan sebagai berikut:

1. Return on assets, corporate governance dan karakter eksekutif secara simultan berpengaruh signifikan terhadap tax avoidance. Hal ini dibuktikan dengan tingkat signifikan sebesar $0,000<0,05$, maka dapat disimpulkan dalam penelitian ini $\mathrm{H} 0$ ditolak dan $\mathrm{H} 1$ diterima.

2. Return on assets berpengaruh signifikan terhadap tax avoidance. Hal ini dibuktikan dengan tingkat signifikan sebesar 0,015 < 0,05, maka dapat disimpulkan dalam penelitian ini $\mathrm{H} 0$ ditolak dan $\mathrm{H} 2$ diterima. Hal ini menunjukkan bahwa Laba yang meningkat berakibat pada ROA yang juga meningkat. Meningkatnya laba berdampak pada pajak terutang yang semakin besar. Perusahaan akan berupaya untuk mengecilkan atau meminimalkan pajak yang terutang. Dengan demikian ada kemungkinan bagi perusahaan untuk melakukan penghindaran pajak.

3. Kepemilikan institusionalberpengaruh signifikan terhadap tax avoidance. Hal ini dibuktikan dengan tingkat signifikan sebesar $0,000<0,05$, maka dapat disimpulkan dalam penelitian ini $\mathrm{H} 0$ ditolak dan $\mathrm{H} 3$ diterima. Hal ini menunjukkan bahwa semakin besar kepemilikan institusional maka semakin kuat kendali pihak eksternal terhadap perusahaan, sehingga memungkinkan terjadinya praktik penghindaran pajak (tax avoidance).

4. Komisaris independen berpengaruh signifikan terhadap tax avoidance. Hal ini dibuktikan dengan tingkat signifikan sebesar $0,032<0,05$, maka dapat disimpulkan dalam penelitian ini $\mathrm{HO}$ ditolak dan $\mathrm{H} 4$ diterima. Hal ini menunjukkan bahwa semakin besarnya persentase dewan komisaris independen dalam struktur dewan komisaris maka semakin tinggi penghindaran pajak yang ditimbulkan.

5. Komite audit tidak berpengaruh signifikan terhadap tax avoidance. Hal ini dibuktikan dengan tingkat signifikan sebesar $0,185>$ 0,05, maka dapat disimpulkan dalam penelitian ini $\mathrm{H} 0$ diterima dan $\mathrm{H} 5$ ditolak. Hal ini menunjukkan bahwa semakin tinggi keberadaan komite audit dalam perusahaan akan meningkatkan kualitas good corporate governance di dalam perusahaan, sehingga akan memperkecil kemungkinan praktik penghindaran pajak yang dilakukan

Risiko perusahaan tidak berpengaruh signifikan terhadap tax avoidance. Hal ini dibuktikan dengan tingkat signifikan sebesar 
$0,077>0,05$, maka dapat disimpulkan penelitian ini H0 diterima dan H6 ditolak. Hal ini menunjukkan bahwa perusahaan yang memiliki risiko perusahaan tinggi atau eksekutifnya risk taker cenderung menyajikan laporan keuangan lebih apa adanya untuk melihat seberapa jauh kinerja yang telah dilakukan oleh perusahaan sehingga peluang untuk melakukan tax avoidance menjadi rendah.

\section{B. Saran}

Berdasarkan kesimpulan yang telah dibuat, maka timbul saran yang dapat dijadikan pertimbangan untuk penelitian selanjutnya. Oleh karena itu berikut diuraikan beberapa hal untuk kesempurnaan penelitian selanjutnya:

1. Variabel komite audit untuk penelitian selanjutnya diharapkan dapat menggunakan perusahaan sampel dengan pengukuran komite audit yang berbeda sehingga data yang diperoleh lebih bervariasi yang mungkin lebih berpengaruh terhadap tax avoidance.

2. Variabel risiko perusahaan untuk penelitian selanjutnya diharapkan dapat menggunakan perusahaan sampel dengan nilai standardeviasi ebitda lebih besar dibandingkan dengan total asset yang mungkin lebih berpengaruh terhadap tax avoidance.

3. Penelitian ini hanya menggunakan perusahaan pertambangan yang terdaftar di Bursa Efek Indonesia sebagai objek penelitiannya, sehingga belum mencakup keseluruhan jenis perusahaan yang ada. Diharapkan pada penelitian selanjutnya

\section{DAFTAR PUSTAKA}

Agoes, S., \& Ardana, I. C. (2014). Etika Bisnis dan Profesi. Jakarta: Salemba Empat.

Ali, M. (2006). Manajemen Risiko. Jakarta: Rajawali Pers.

Alviyani, K., Surya, R. A., \& Rofika. (2016). Pengaruh Corporate Governance, Karakter Eksekutif, Ukuran Perusahaan dan Leverage Terhadap Penghindaran dapat mengambil objek penelitian yang lebih banyak.

4. Penelitian ini hanya mengambil sampel 5 tahun Laporan Keuangan dan Annual Report pada masing-masing perusahaan. Diharapkan penelitian selanjutnya dapat memperpanjang sampel penelitian sehingga observasi menjadi lebih lama dan mendapatkan hasil yang maksimal.

5. Untuk memperoleh hasil yang lebih baik, penelitian selanjutnya diharapkan dapat memperluas populasi penelitian dan tidak hanya terbatas pada perusahaan pertambangan saja. Sebaiknya menambah periode penelitiannya sehingga dapat diketahui pengaruh penelitian dalam jangka waktu yang panjang.

6. Penelitian selanjutnya diharapkan dapat tidak terpaku dengan kelima variabel yang terdapat dalam penelitian ini, karena beberapa variabel dalam penelitian ini diantaranya komite audit dan risiko perusahaan tidak berpengaruh terhadap tax avoidance. namun, peneliti selanjutnya diharapkan dapat menambah variabel-variabel lain yang mungkin dapat berpengaruh terhadap tax avoidance, sehingga hasil penelitian dapat menjelaskan semua kontribusi variabelvariabel terhadap praktik tax avoidance pada perusahaan.

7. Penelitian selanjutnya juga perlu menambahkan variabel lain seperti Kompensasi Eksekutif, Struktur Dewan Komisaris, Struktur Kepemilikan Publik, Multinational Cpompany dan lain-lain. 
Annisa, Taufik, T., \& Hanif, R. A. (2017). Pengaruh Return on Asset, Leverage, Ukuran Perusahaan dan Koneksi Politik Terhadap Penghindaran Pajak. JOM Fekon Vol. 4, No.1, 685-698.

Butje, S., \& Tjondro, E. (2014). Pengaruh Karakter Eksekutif dan Koneksi Politik Terhadap Tax Avoidance. Tax and Accounting Review Vol. 4, No. 2, 1-9.

Cahyono, D. D., Andini, R., \& Raharjo, K. (2016). Pengaruh Komite Audit, Kepemilikan Institusional, Dewan Komisaris, Ukuran Perusahaan (Size), Leverage (DER), Profitabilitas (ROA) Terhadap Tindakan Penghindaran Pajak (Tax Avoidance). Journal of Accounting Vol. 2, No. 2, 1-10.

Damayanti, F., \& Susanto, T. (2015). Pengaruh Komite Audit, Kualitas Audit, Kepemilikan Institusional, Risiko Perusahaan dan Return on Assets Terhadap Tax Avoidance. Jurnal Bisnis dan Manajemen Vol. 5, No. 2, 187-206.

Darmawan , I. H., \& Sukartha, I. (2014). Pengaruh Penerapan Corporate Governance, Leverage, Return on Assets dan Ukuran Perusahaan Pada Penghindaran Pajak. E-Jurnal Akuntansi Universitas Udayana Vol. 9 , No. 1, 143-161.

Dewi, N. K., \& Jati, I. (2014). Pengaruh Karakter Eksekutif, Karakteristik Perusahaan dan Dimensi Tata Kelola Perusahaan yang Baik Pada Tax Avoidance. E-Jurnal Akuntansi Universitas Udayana Vol. 6, No. 2, 249-260.

Dewi, N., Nasir, A., \& Hariadi. (2016). Pengaruh Karakter Eksekutif, Karakteristik Perusahaan dan Pengungkapan Tanggung Jawab Sosial Perusahaan Terhadap Penghindaran
Pajak. JOM Fekon Vol. 3, No. 1, 10061020.

Diantari, P. R., \& Ulupui, I. A. (2016). Pengaruh Komite Audit, Proporsi Komisaris Independen dan Korporasi Kepemilikan Institusional Terhadap Tax Avoidance. E-Jurnal Akuntansi Universitas Udayana Vol. 16, No. 1, 702-732.

Forum Pajak Minta Transparansi Perpajakan Tambang. (2018, Maret 20). Retrieved from Suara Pembaruan: http://sp.beritasatu.com

Ghozali, I. (2013). Aplikasi Analisis Multivariet dengan Program IBM SPSS 23. Semarang: Badan Penerbit Universitas Diponegoro.

Gunawan, R. M. (2016). GRC (Good Governance, Risk Management and Compliance). Jakarta:

PT. Raja Grafindo Persada.

Hery. (2014). Controllership: Manajemen Strategis, Pengendalian Internal, Analisis Keuangan. Jakarta: PT Grassindo.

Hery. (2017). Teori Akuntansi. Jakarta: PT. Grasindo.

Hidayati, N., \& Fidiana. (2017). Pengaruh Corporate Social Responsibility dan Good Corporate Governance Terhadap Penghindaran Pajak. Jurnal Ilmu dan Riset Akuntansi Vol. 6 No. 3, 10521070.

Lestari, G. A., \& Putri, I. A. (2017). Pengaruh Corporate Governance, Koneksi Politik dan Leverage Terhadap Tax Avoidance. E-Jurnal Akuntansi Universitas Udayana Vol. 18, No. 3, 2028-2054.

Maharani, I. A., \& Suardana, K. A. (2014). Pengaruh Corporate Governance, Profitabilitas dan Karakter Eksekutif 
Pada Tax Avoidance. E-Jurnal Akuntansi Universitas Udayana Vol. 9, No. 2, 525-539.

Nursari, M., Diamonalisa, \& Sukarmanto, E. (2017). Pengaruh Profitabilitas, Leverage dan Kepemilikan Institusional Terhadap Tax Avoidance. Porsiding Akuntansi Vol. 3, No. 2, 259-266.

Okrayanti, T. Y., Utomo, S. W., \& Nuraina, E. (2017). Pengaruh Karakteristik Perusahaan dan Corporate Governance Terhadap Tax Avoidance. Forum Ilmiah Pendidikan Akuntansi Vol. 5, No. 1, 804-817.

Pohan, C. A. (2013). Manajemen Perpajakan Strategi Perencanaan Pajak dan Bisnis. Jakarta: PT.

Gramedia Pustaka Utama.

Prasetyantoko, A. (2008). Corporate Governance. Jakarta: PT. Gramedia Pustaka Utama.

Purwono, H. (2010). Dasar-Dasar Perpajakan dan Akuntansi Pajak. Jakarta: Erlangga.

Rahayu, S. K. (2010). Perpajakan Indonesia. Yogyakarta: Graha Ilmu.

Sandy, S., \& Lukviarman, N. (2015). Pengaruh Corporate Governance Tehadap Tax Avoidance.

JAAI Vol. 19 No. 2, 85-98.

Saputra, $\quad$ M. D., \& Asyik, N. F. (2017). Pengaruh Profitabilitas, Leverage dan Corporate Governance Terhadap Tax Avoidance. Jurnal Ilmu dan Riset Akuntansi Vol. 6, No. 8, 01-19.

Saputra, M. F., Rifa, D., \& Rahmawati, N. (2015). Pengaruh Corporate Governance, Profitabilitas dan Karakter Ekseskutif Terhadap Tax Avoidance. JAAI Vol. 19, No. 1, 1-12.
Siahaan, H. (2009). Manajemen Risiko Pada Perusahaan dan Birokrasi. Jakarta: PT. Elex Media Komputindo.

Simanjuntak, J. (2017, November 20). Indonesia Masuk Peringkat ke-11 Penghindaran Pajak Perusahaan, Jepang No.3. Retrieved from Tribunnews: http://www.tribunnews.com

Soegoto, E. S. (2010). Entrepreneurship Sebagai Pebisnis Ulung. Jakarta: PT. Elex Media Komputindo.

Suandy, E. (2008). Perencanaa Pajak. Jakarta: Salemba Empat.

Sugiono, A., \& Untung, E. (2008). Panduan Praktis Dasar Analisa Laporan Keuangan. Jakarta: PT. Grassindo.

Sulistyanto, S. (2008). Manajemen Laba. Jakarta: PT. Grasindo.

Sumarsan, T. (2013). Tax Review dan Strategi Perencanaan Pajak. Jakarta: PT. Indeks.

Susilo, R. (2017, November 20). Indonesia Masuk Peringkat ke-11 Penghindaran Pajak Perusahaan, Jepang No.3. Retrieved from Tribunnews: http://www.tribunnews.com

Swingly, C., \& Sukartha, I. (2015). Pengaruh Karakter Eksekutif, Komite Audit, Ukuran Perusahaan, Leverage dan Sales Growth pada Tax Avoidance. E-jurnal Akuntansi Universitas Udayana Vol. 10, No, 1, 47-62.

Ulum, M. C. (2012). Leadership Dinamika Teori Pendekatan dan Isu Strategis Kepemimpinan di Sektor Publik. Malang: Universitas Brawijaya Press (UB Press). 
Wahyudiono, B. (2014). Mudah Membaca Laporan Keuangan. Jakarta: Niaga Swadaya.

Wibawa,

A., Wilopo, \& Abdillah, Y. (2016). Pengaruh Corporate Governance Terhadap Penghindaran Pajak. Jurnal Perpajakan (JEJAK) Vol. 11, No. 1, 1-9.

Wijaya, I. (2014, Agustus 12). Mengenal Penghindaran Pajak, Tax Avoidance. Retrieved from Direktorat Jenderal Pajak Kementerian Keuangan: http://www.pajak.go.id

Winata, F. (2014). Pengaruh Corporate Governance Terhadap Tax Avoidance pada Perusahaan yang Terdaftar di Bursa Efek Indonesia Tahun 2013. Tax \& Accounting Review Vol. 4, No. $1,1-11$. 